Article

\title{
Classification and Characterization of the Manoor Valley's (Lesser Himalaya) Vegetation from the Subtropical-Temperate Ecotonal Forests to the Alpine Pastures along Ecological Variables
}

\author{
Inayat Ur Rahman 1,2,*D, Aftab Afzal 1,*, Zafar Iqbal 1, Mashail Nasser Alzain ${ }^{3}$, Al-Bandari Fahad Al-Arjani ${ }^{4}$, \\ Abdulaziz A. Alqarawi ${ }^{5}$, Elsayed Fathi Abd_Allah ${ }^{5}{ }^{(D}$, Niaz Ali $^{1}{ }^{(D}$, Shazia Sakhi ${ }^{6}$, Muhammad Azhar Khan ${ }^{1}$, \\ Uzma Khan $^{1}$, Farhana Ijaz ${ }^{1, *}$, Samina Mumtaz ${ }^{7}$ and Eduardo Soares Calixto ${ }^{8,9}$ (D)
}

check for updates

Citation: Rahman, I.U.; Afzal, A.; Iqbal, Z.; Alzain, M.N.; Al-Arjani, A.-B.F.; Alqarawi, A.A.; Abd_Allah, E.F.; Ali, N.; Sakhi, S.; Khan, M.A.; et al. Classification and

Characterization of the Manoor Valley's (Lesser Himalaya) Vegetation from the Subtropical-Temperate Ecotonal Forests to the Alpine Pastures along Ecological Variables. Plants 2022, 11, 87. https://doi.org/ $10.3390 /$ plants 11010087

Academic Editor:

Daniel Sánchez-Mata

Received: 8 October 2021

Accepted: 29 November 2021

Published: 28 December 2021

Publisher's Note: MDPI stays neutral with regard to jurisdictional claims in published maps and institutional affiliations.

Copyright: (c) 2021 by the authors. Licensee MDPI, Basel, Switzerland. This article is an open access article distributed under the terms and conditions of the Creative Commons Attribution (CC BY) license (https:// creativecommons.org/licenses/by/ $4.0 /)$.
1 Department of Botany, Hazara University, Mansehra 21300, Pakistan; zafar.iqbal@hu.edu.pk (Z.I.); niazalitk25@gmail.com (N.A.); azharfinal@gmail.com (M.A.K.); uzmaqau2003@yahoo.com (U.K.)

2 William L. Brown Center, Missouri Botanical Garden, 4344 Shaw Blvd, St. Louis, MO 63110, USA

3 Department of Biology, College of Sciences, Princess Nourah Bint Abdulrahman University, Riyadh 11451, Saudi Arabia; mnAlZain@pnu.edu.sa

4 Botany and Microbiology Department, College of Science, King Saud University, Riyadh 11451, Saudi Arabia; aalarjani@ksu.edu.sa

5 Department of Plant Production, College of Food and Agriculture Science, King Saud University, Riyadh 11451, Saudi Arabia; alqarawi@ksu.edu.sa (A.A.A.); eabdallah@ksu.edu.sa (E.F.A.)

6 Center of Plant Sciences and Biodiversity, University of Swat, Swat 19200, Pakistan; shaziasakhi@gmail.com

7 Department of Animal Sciences, Karakoram International University, Gilgit-Baltistan 15100, Pakistan; samina@kiu.edu.pk

8 Department of Biology, University of Missouri, St. Louis, MO 63166, USA; calixtos.edu@gmail.com

9 Entomology and Nematology Department, University of Florida, Gainesville, FL 32611, USA

* Correspondence: hajibotanist@outlook.com (I.U.R.); draftab@hu.edu.pk (A.A.); fbotany@yahoo.com (F.I.)

Abstract: Plant species are distributed in different types of habitats, forming different communities driven by different sets of environmental variables. Here, we assessed potential plant communities along an altitudinal gradient and their associations with different environmental drivers in the unexplored Manoor Valley (Lesser Himalaya), Pakistan. We have implemented various ecological techniques and evaluated phytosociological attributes in three randomly selected $50 \mathrm{~m}$-transects within each stand (a total of 133) during different seasons for four years (2015-2018). This phytosociological exploration reported 354 plant species representing 93 different families. The results revealed that the Therophytic life form class dominated the flora, whereas Nanophyll dominated the leaf size spectra. There were a total of twelve plant communities identified, ranging from the lowest elevations to the alpine meadows and cold deserts. The maximum number of species were found in Cedrus-Pinus-Parrotiopsis community (197 species), in the middle altitudinal ranges (2292-3168 m). Our results showed that at high altitudes, species richness was reduced, whereas an increase in soil nutrients was linked to progression in vegetation indicators. We also found different clusters of species with similar habitats. Our study clearly shows how altitudinal variables can cluster different plant communities according to different microclimates. Studies such as ours are paramount to better understanding how environmental factors influence ecological and evolutionary aspects.

Keywords: vegetation structure; environmental variables; PC-ORD; plant community assembly; Himalaya

\section{Introduction}

The study of vegetation classification based on species co-occurrence [1,2] and its relationship to ecological variables [3] is known as phytosociology. This field has specified major 
strategies and methodologies that may be linked to vegetation mapping $[4,5]$, and biodiversity conservation [6]. Plant biodiversity research generally focuses on species diversity [7-9] and species-level measurement [10]. It is greatly influenced by a variety of environmental variables [11-13], such as climatic, edaphic, and geographic variables [13-18]. Plant associations/communities with a well-defined structure in respect to ecological variables can be described physiognomically as well as floristically [19-21]. Floristic diversity and biological spectra rely on topography as well as other environmental variables. For instance, biological spectrum mirrors the existing ecological and natural surroundings [22,23]. They are the plant characteristics that have been widely applied in vegetation research [24]. High mountains are major hotspots for endemics across the world [25-28].

It is well understood that altitude is a complex factor along which many environmental gradients [29] and species diversity [15,30] change accordingly. Biological as well as the environmental gradients interact to govern the distribution of species richness all around the altitudinal gradient [31-33]. The species richness of higher plant species has been reported to have increased in temperate latitudes [34]. The relationship between vegetation and ecological diversity is reflected as a percentage of the ecosystem's overall quality [35]. The altitudinal gradient has a greater influence on temperature in mountainous regions than latitude, and the rate of decrease is considerably faster in summer than in winter, resulting in altitudinal vegetation zonation [29].

Plant species are found in a diverse range of environments, forming different communities driven by different sets of environmental variables [6,36,37]. Many ecological experts have recognized distinct types of forests in Pakistan [38-41], but it is not clear how and which environmental variables drive plant diversity and community structure in most alpine ecosystems. In this context, we used different multivariate approaches to assess potential plant communities along an altitudinal gradient and their associations with different environmental drivers, namely climatic, edaphic, and physiographic variables. In sum, we assessed (i) which potential plant communities are present in the subtropical-temperate ecotonal forests to the alpine pastures; (ii) which plant species are most representative each plant community; (iii) which environmental variables most determine plant community structure in this region; and (iv) which species are distribution in each community based on their biological spectrum (life form and leaf size). Since there is a significant variability in environmental gradients with respect to the altitude and different plant species are adapted to a set of micro-climatic conditions [42-44], we hypothesized that there would be different plant communities along the elevational gradient, with specific plants related to particular sets of environmental variables. Importantly, statistical methodologies in vegetation ecology, such as multivariate analysis [45], have evolved in recent decades, allowing researchers to evaluate the impact of ecological variables on large groups of plants [6,43,46-48]. Therefore, we took advantage of these advanced statistical approaches to assess viable low-dimensional summaries of field information by advantageous and objective means [49].

\section{Materials and Methods}

\subsection{Study Area}

Geographically, the Manoor Valley [4,50,51] is situated in the north-western part of Pakistan ( $34.68165 \mathrm{~N}$ to $34.83869 \mathrm{~N}$ latitude and $73.57520 \mathrm{E}$ to $73.73182 \mathrm{E}$ longitude; 1580 to $4677 \mathrm{~m}$ elevation above sea level) and is part of the Himalayan mountain range. The multiple elevational layers of the research area are depicted on a georeferenced map (Figure 1). The wide gap in in elevation demonstrates that the climate differs from lower altitudinal ranges [4] to the alpine meadows [42]. The study area is located on the Indian Plate's northwestern boundary [52], which has immense phytogeographic and floristic significance. 


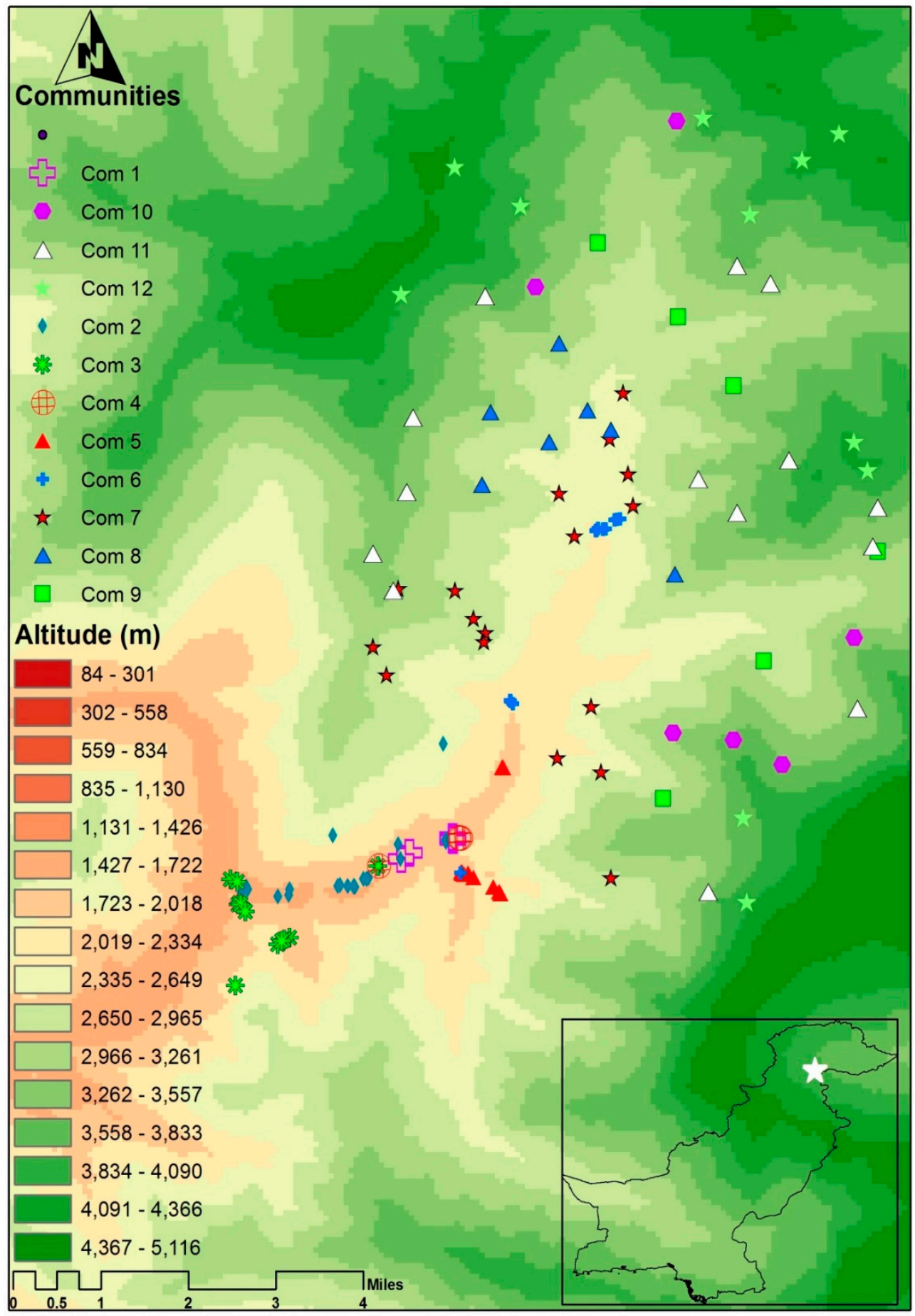

Figure 1. GIS map (generated using ArcGIS version 10.1) depicting the altitudinal layers and distribution pattern of communities of the studied area (Manoor Valley). Com 1: Salix-Sorbaria-Impatiens, Com 2: Indigofera-Juglans-Isodon, Com 3: Cedrus-Cynodon-Isodon, Com 4: Indigofera-ParrotiopsisBistorta, Com 5: Sambucus-Cedrus-Desmodium, Com 6: Indigofera-Cedrus-Pinus, Com 7: Cedrus-PinusParrotiopsis, Com 8: Pinus-Viburnum-Cedrus, Com 9: Abies-Picea-Juniperus, Com 10: Juniperus-SibbaldiaJuniperus, Com 11: Sibbaldia-Bergenia-Rheum, Com 12: Poa-Bistorta-Primula.

\subsection{Vegetation Sampling and Herbarium work}

The vegetation of the study area (Manoor Valley) was surveyed and quantified [53] during four consecutive years, from 2015 to 2018, along the environmental variables [43]. The line transect method was adopted for vegetation sampling [54-58]. The study area was 
subdivided into 133 stands (sampling plots). Each stand was replicated thrice (three transects of $50 \mathrm{~m}$ in each stand) $[53,59]$. The interval between each transect was $100 \mathrm{~m}$ and the interval between the stands was $200 \mathrm{~m}$. The phytosociological attributes (i.e., density, frequency and their relative values, and importance value (IV)) were employed on the recorded data of each stand $[4,60,61]$. The species were further ranked with the highest IV and considered the representative species $[19,62]$. Similarly, plant communities were designated based on three dominant species [63-66]. Moreover, both attributes of the biological spectrum (life form and leaf size spectra) were recognized by the following [67]. Methods for collecting specimens, their labelling, pressing, drying, poisoning, and mounting were adopted by the following [68,69]. Their identification was achieved with the aid of Flora of Pakistan [70-72] and submitted to the Herbarium of Hazara University, Mansehra (Pakistan).

\subsection{Ecological Variables}

The slope angle, aspect and exposure were recorded at each stand using a clinometer, while the altitude, longitude, and latitude were recorded by the Global Positioning System (GPS). Two hundred grams of soil samples from three randomly selected transects within each sampling stand (0-30 cm depth) were collected [73] and mixed thoroughly to make a composite sample [74], stored in a sterile polythene bag and labeled. All the samples were submitted to the Soil and Water Testing Laboratory at the Model Farm Service Center in Mansehra, Pakistan, for analysis of various physicochemical parameters such as soil $\mathrm{pH}$ [75], and texture (loam, clay, silt and sand) [76], organic matter (OM\%) [77], nitrogen (N) [78], potassium (K), phosphorous (P) [79], calcium carbonate $\left(\mathrm{CaCO}_{3}\right)$ [80-82], and electric conductivity (EC) [76]. Moreover, other climatic variables were measured by a small remote weather station (Kestrel 4000 weather and environmental tracker) like temperature, humidity, wind speed (WS), barometric pressure (BP), wet bulb (WB), heat index (HI), and dew point (DP) to record the data at each transect and then average values were calculated at stand level [43].

\subsection{Statistical Analyses}

Multivariate analysis was carried out to analyze the recorded data of species and ecological variables resulting from the field observations $[49,83]$ to find out the relationship among them $[84,85]$. The recorded species and sampled stands were constrained in association to the ecological variables [86,87], which were divided into geographic, slope aspect, edaphic, and climatic variables. For the identification and classification of plant communities [53], the two-way indicator species analysis (TWINSPAN) was processed using PC-ORD version 5.0 [87-89]. A georeferenced map was generated with ArcGIS version 10.1 to depict the distribution pattern of plant communities.

Canonical correspondence analysis (CCA) was used to ordinate species and samples along the ecological variables $[90,91]$ using CANOCO version $5[92,93]$, and we performed a variation partitioning test (partial CCA) to evaluate how explanatory attributes (climatic, edaphic, geographic, and slope) drive the plant species distribution. First, we built the best model with the lowest number of variables (those that most explain variance), through the step function in R. Next, we also evaluated multicollinearity between variables of the final model using Variance Inflation Factor (VIF), and we removed any variable with VIF $>10$, one at a time. Non-multidimensional scaling ordination (NMDS) [89,94] was performed using the software R 4.0.1 [95-97]. NMDS was conducted to evaluate the correlation of recognized plant communities with their associated species.

\section{Results}

A total of 12 plant communities were recognized, each representing for different indicator species. Each community was associated to a set of variables, but altitude, Slope (ES), Slope (SE), Slope (SW), Slope (WN), electric conductivity (EC) and heat index were the most significant variables driving species distribution in the present study. Therophytes and 
Hemicryptophytes, and Nanophyll, were the most frequent type of life form and leaf size, respectively, present in the communities found. Below we discuss these results in detail.

\subsection{TWINSPAN Classification}

TWINSPAN, which is based partitioning reciprocal averaging ordination space, was used to classify 354 species and 133 stands. Two large different clusters, which show a high cluster heterogeneity value (Lambda $=0.814$ ). One of these clusters had eight different communities and was formed by 93 sampling sites, while the other cluster presented four communities structured into 40 sites. Furthermore, different subdivisions observed were within these two large groups with cluster heterogeneity values of less than 0.4: a total of 12 major plant communities were recognized, from subtropical-temperate ecotonal forests $(1580 \mathrm{~m})$ to the alpine meadows and cold deserts (4278 $\mathrm{m}$ ) of the Manoor Valley, Lesser Himalayas. Each community was composed of different groups of indicator species recorded at different altitudes (Figure 1).

\subsection{Vegetation Characterization of Plant Communities}

In total, 12 major plant communities were established by TWINSPAN. All the twelve recognized plant communities were indicated with distinct symbols and colours. The GIS map shows the elevational layer and communities of the study area-illustrating the recognition and distribution of plant communities (Figure 1) along the ecological variables (Figures 2 and 3 and Supplementary data Figures S1-S4).

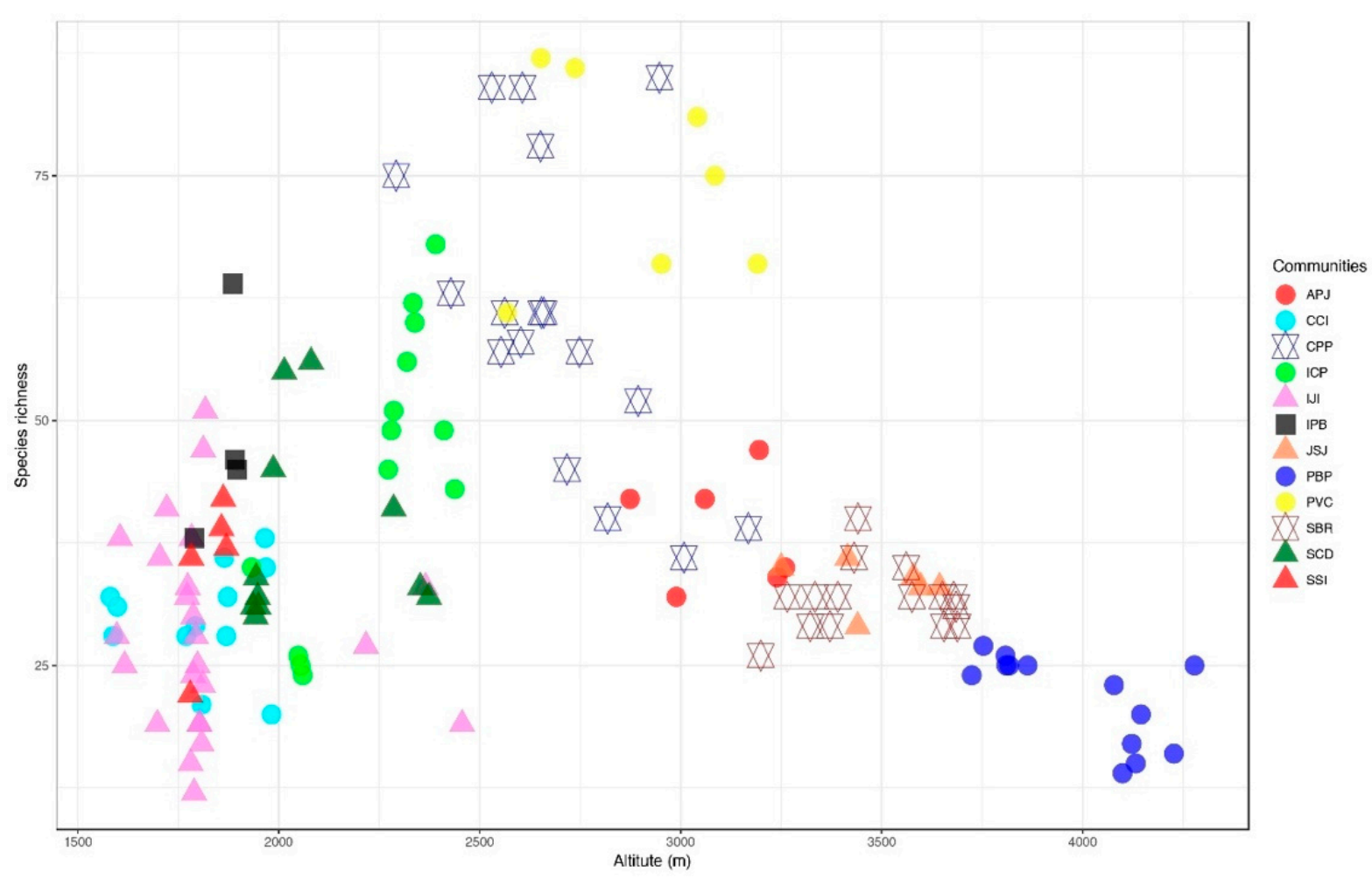

Figure 2. The relationship between the altitude and the species richness of 12 plant communities. 


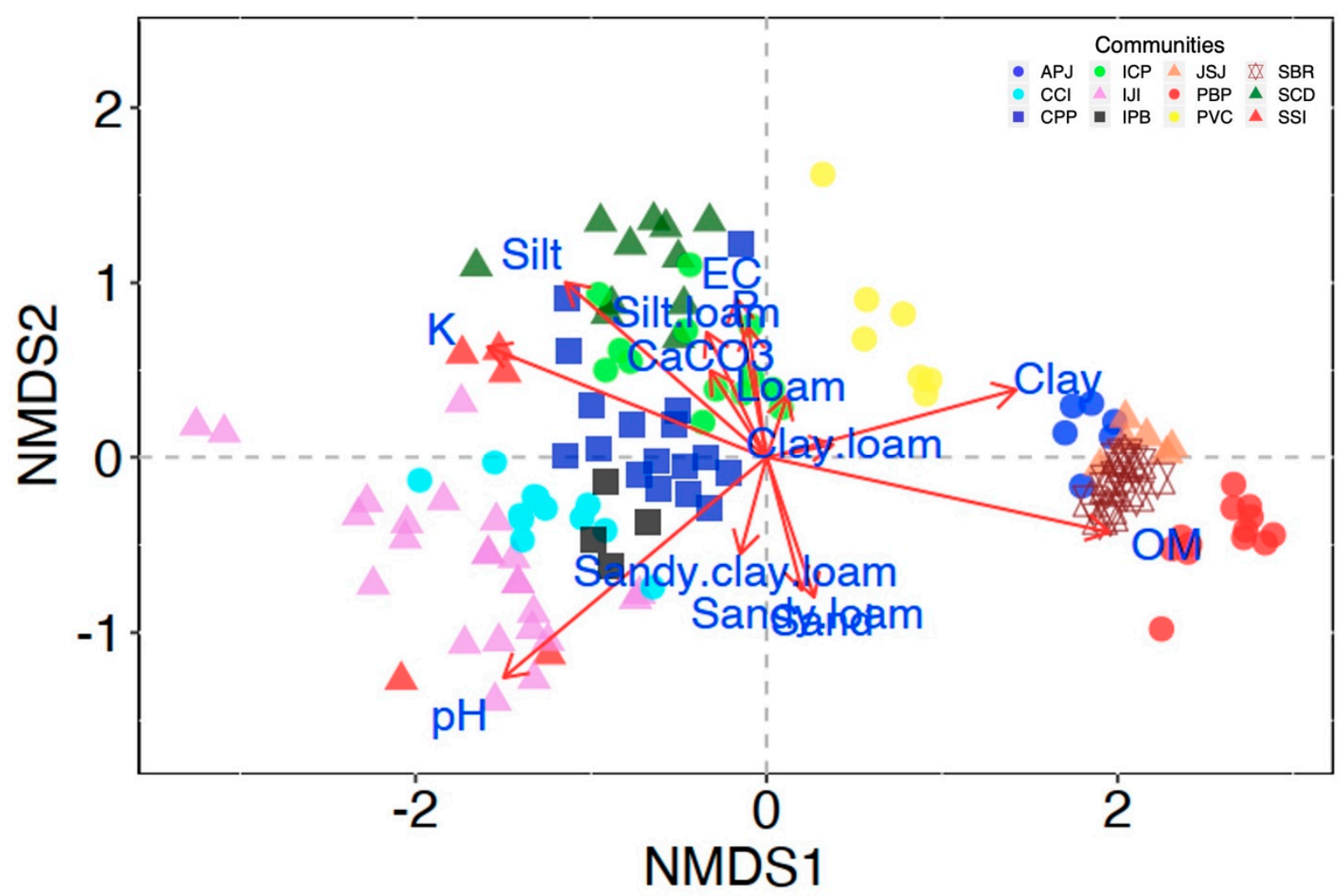

Figure 3. The NMDS ordination reveals the relationship between communities and edaphic variables. The length of the arrows illustrates the influence range, while the direction shows the correlation of the variables with plant communities. Plant communities that are close together or on the same axis have a positive correlation. The codes represent community types.

\subsubsection{Salix-Sorbaria-Impatiens Community}

This community (SSI) was recorded between altitudinal ranges of $1782.3-1869.5 \mathrm{~m}$ (5 stands) with 65 associated species. The indicator plant species of the SSI community were Salix alba, Sorbaria tometosa and Impatiens bicolor with highest IV values of 9.12, 5.51, and 5.29, respectively. Other frequent species were Clematis grata, Bromus secalinus, Fragaria nubicola, Rumex nepalensis, Ficus carica, Salvia moorcroftiana, Indigofera heterantha, Bistorta amplexicaulis, Crotalaria sp., Filipendula vestita and Desmodium elegans. Rare species with lower IV values included Withania somnifera, Trachyspermum amii, Clinopodium vulgare, Paspalum dilatatun, Piptatherum aequiglume, Bauhinia variegata and Salix tetrasperma. The life form spectra was dominated by Therophytes (36.92\% of species), followed by Hemicryptophytes with $15.38 \%$ of species (Table 1). Nanophyll dominated the leaf size spectra with $30.77 \%$ of the species, followed by Mesophyll and Microphyll with $27.69 \%$ species each (Table 1). The ecological variables that strong and positively influenced the SSI community were $\mathrm{pH}$ (6.5-7), temperature $\left(26.1-27.2^{\circ} \mathrm{C}\right), \mathrm{HI}(26.8-29.1)$, and BP (808.1-816.1) (Supplementary data Figure S1). Other important variables such as altitude and windspeed $(0-1.5 \mathrm{~m} / \mathrm{s})$ were found in negative association with SSI community. Nevertheless, the SSI community's species diversity was restricted by low OM $(0.65-1.15 \%)$ and $\mathrm{P}(9.6 \mathrm{mg} / \mathrm{kg}$ ) (Figure 3 and Supplementary data Figure S2). 
Table 1. Percentage of plant species recorded in each plant community according to the biological spectrum (life form) and leaf size.

\begin{tabular}{|c|c|c|c|c|c|c|c|c|c|c|c|c|}
\hline & \multicolumn{12}{|c|}{ Plant Communities } \\
\hline & SSI & IJI & CCI & IPB & SCD & ICP & CPP & PVC & APJ & JSJ & SBR & PBP \\
\hline \multicolumn{13}{|l|}{ Life form } \\
\hline Chamaephytes & 9.23 & 10.71 & 12.68 & 10.23 & 10.68 & 7.09 & 8.79 & 5.94 & 9.84 & 0.00 & 12.00 & 12.82 \\
\hline Geophytes & 4.62 & 5.36 & 9.86 & 6.82 & 7.77 & 9.22 & 0.00 & 11.39 & 9.84 & 11.36 & 8.00 & 10.26 \\
\hline Hemicryptophytes & 15.38 & 22.32 & 25.35 & 25.00 & 0.00 & 25.53 & 27.47 & 30.69 & 40.98 & 56.82 & 48.00 & 53.85 \\
\hline Liana & 3.08 & 0.89 & 2.82 & 1.14 & 1.94 & 0.00 & 1.65 & 0.99 & 0.00 & 0.00 & 0.00 & 0.00 \\
\hline Megaphanerophytes & 0.00 & 3.57 & 2.82 & 1.14 & 5.83 & 2.13 & 1.65 & 2.97 & 6.56 & 0.00 & 0.00 & 0.00 \\
\hline Mesophanerophytes & 13.85 & 7.14 & 0.00 & 3.41 & 9.71 & 4.96 & 2.75 & 1.98 & 3.28 & 0.00 & 0.00 & 0.00 \\
\hline Microphanerophytes & 4.62 & 5.36 & 1.41 & 3.41 & 0.97 & 2.13 & 0.55 & 0.50 & 0.00 & 2.27 & 0.00 & 0.00 \\
\hline Nanophanerophytes & 12.31 & 10.71 & 9.86 & 11.36 & 19.42 & 11.35 & 14.84 & 11.88 & 0.00 & 11.36 & 8.00 & 0.00 \\
\hline Parasitic & 0.00 & 0.89 & 1.41 & 1.14 & 0.00 & 0.00 & 0.00 & 0.00 & 0.00 & 0.00 & 0.00 & 0.00 \\
\hline Therophytes & 36.92 & 33.04 & 33.80 & 36.36 & 43.69 & 37.59 & 42.31 & 33.66 & 29.51 & 18.18 & 24.00 & 23.08 \\
\hline \multicolumn{13}{|l|}{ Leaf size } \\
\hline Aphyllous & 1.54 & 0.89 & 1.33 & 1.14 & 0.76 & 1.42 & 0.00 & 0.00 & 1.52 & 2.04 & 2.00 & 2.63 \\
\hline Leptophyll & 10.77 & 10.71 & 10.67 & 15.91 & 19.08 & 17.02 & 17.77 & 16.84 & 24.24 & 26.53 & 28.00 & 21.05 \\
\hline Macrophyllous & 1.54 & 5.36 & 6.67 & 1.14 & 6.11 & 7.09 & 5.58 & 5.61 & 3.03 & 2.04 & 2.00 & 2.63 \\
\hline Mesophyll & 27.69 & 20.54 & 10.67 & 13.64 & 14.50 & 16.31 & 14.72 & 15.31 & 10.61 & 14.29 & 10.00 & 15.79 \\
\hline Microphyll & 27.69 & 26.79 & 30.67 & 22.73 & 28.24 & 26.95 & 30.96 & 28.06 & 27.27 & 20.41 & 20.00 & 28.95 \\
\hline Nanophyll & 30.77 & 35.71 & 40.00 & 45.45 & 31.30 & 31.21 & 30.96 & 34.18 & 33.33 & 34.69 & 38.00 & 28.95 \\
\hline
\end{tabular}

\subsubsection{Indigofera-Juglans-Isodon Community}

This plant community (IJI) was recognized in 24 stands at an altitude ranging from 1597 to $2456 \mathrm{~m}$ with 113 associated species (Table 1). Indigofera heterantha, Juglans regia, and Isodon rugosus were recognized as the indicator species that dominated the community with IV values of 6.94, 5.00, and 4.37, respectively. Other co-dominant species were Cynodon dactylon, Ziziphus sp., Micromeria biflora, Leptopus chinensis, Rumex hastatus, Ailanthus altissima and Impatiens bicolor. Moreover, species that were rarely recorded in this community were Dactylis glomerata, Achyranthes aspera, Lamium album, Bupleurum longicaule, Ricinus communis, Malus domestica, Pyrus pashia, Dodonaea viscosa, Filipendula vestita, Lactuca tatarica, Pinus roxburghii and Xanthium strumarium. Therophytes dominated the biological spectrum with $33.04 \%$ of plant species, followed by Hemicryptophytes (22.32\%), Chamaephytes and Nanophanerophytes (10.71\%) each (Table 1). Nanophyllous class dominated the leaf size spectra, accounting for $35.71 \%$ of plant species, followed by microphyll $(26.79 \%)$, and mesophyll (20.54\%). The IJI community was supported by abundant limestone, granite, and sandstone. High temperatures $\left(32.5^{\circ} \mathrm{C}\right), \mathrm{pH}(5.7-7.1), \mathrm{K}(200-235 \mathrm{mg} / \mathrm{kg})$, and $\mathrm{HI}(26.8-29.1)$ all had an impact on the indicators of the IJI community and their associated species, which were distributed on a slope angle of $28-75^{\circ}$ (Figure 3 and Supplementary data Figures S1-S4).

\subsubsection{Cedrus-Cynodon-Isodon Community}

This community (CCI) was recognized in 12 stands between altitudes of 1580.8-1982 m. Cedrus deodara (11.77 IV), Cynodon dactylon (10.42 IV) and Isodon rugosus (6.02 IV) were recorded as the leading indicators of this plant community. Other co-dominant species were Dryopteris wallichiana, Oxalis corniculate, Medicago sativa, Cyperus rotundus, Fragaria nubicola, Adiantum capillus-veneris, Impatiens bicolor, Trifolium repens, Clematis grata, Artemisia absinthium, Leptodermis virgata, Convolvulus arvensis, Tagetes minuta, Cirsium arvense, Persicaria capitata and Hedera nepalensis. Nonetheless, Silybum marianum, Dicliptera bupleuroides, Cichorium intybus, Pteridium aquilinum, Geranium nepalense, Conyza japonica, Malvastrum coromandelianum, Saussurea sp., Pinus roxburghii, Achyranthes bidentata and Pyrus pashia were found 
as the rare species with lower IV values. Therophytes dominated the life form spectra with $33.80 \%$ of species, followed by Hemicryptophytes with $25.35 \%$ of species, Chamaephytes with $12.68 \%$ of species, Nanophanerophytes and Geophytes each with $9.86 \%$ of species (Table 1). Nanophyll dominated the leaf size spectra with $40 \%$ of the species, followed by Microphyll with $30.67 \%$ of the species, and Leptophyll and Mesophyll with $10.67 \%$ of the species. Atmospheric humidity (53.6-74.9\%), DP (15.5-19.1\%), temperature $\left(20.9-28.4{ }^{\circ} \mathrm{C}\right)$, EC (0.56-2.24 dsm $\left.{ }^{-1}\right), \mathrm{OM}(0.6-1.25 \%)$ and $\mathrm{pH}$ (5.9-7.3), were the most influential ecological variables that influenced the composition as well as distribution of plant species of CCI community. Aspect (N-E), slope angle $\left(24-50^{\circ}\right)$, and silty loam soil texture were also important significant variables of the CCI community (Supplementary data Figures S1-S4).

\subsubsection{Indigofera-Parrotiopsis-Bistorta Community}

The IPB community was recognized on the aspect $(\mathrm{W}-\mathrm{N})$ with a slope angle $\left(45-80^{\circ}\right)$ in four stands at an altitudinal range of 1789.6-1896.3 m, which has a total of 87 species associated species (Table 1). Indigofera heterantha, Parrotiopsis jacquemontii, Bistorta amplexicaule were recorded as the dominant species in this community with highest IV values of 12.34, 9.05 and 6.18, respectively. Other characteristic species based IV were Indigofera hebepetala, Clematis grata, Bromus secalinus, Cynodon dactylon, Clinopodium vulgare, Cynoglossum glochidiatum, Urochloa panicoides, Isodon rugosus, Pimpinella stewartia, Berberis lycium, Dysphania ambrosioides, Pyrus pashia and Poa infirma. Rare species of this community with minimum IV values were Leptodermis virgata, Cynoglossum apenninum, Commelina benghalensis, Cannabis sativa, Bergenia ciliata, Crotalaria sp., Malva neglecta, Ficus carica, Salix alba, Achyranthes bidentata, Malvastrum coromandelianum, Cyperus odoratus, Fraxinus hookeri and Malva parviflora. Therophytes dominated the life form spectra with $36.36 \%$ of plant species, followed by Hemicryptophytes with $25 \%$ of species. Nanophyll led the leaf size spectra with $45.45 \%$ of species, followed by Microphyll with $22.73 \%$ of the species (Table 1$)$. The strongest environmental variables of this IPB community were $\mathrm{pH}$ (6.4-6.6), DP (18.6-21.4), and WB (20.8-23.8) and (Supplementary data Figures S1 and S4).

\subsubsection{Sambucus-Cedrus-Desmodium Community}

This plant community (SCD) was recorded with a total of 129 associates in 11 stands between the altitudinal ranges of 1936 to $2373.8 \mathrm{~m}$. Sambucus weightiana (5.25 IV), Cedrus deodara (5.05 IV), Desmodium elegans (4.1 IV) were recognized as the topmost dominant species. Sorbaria tomentosa, Dactylis glomerata, Heracleum candicans, Dryopteris wallichiana, Pennisetum orientale, Onopordum acanthium, Fragaria nubicola, Foeniculum vulgare, Parrotiopsis jacquemontiana and Phragmites latissimus were other co-dominant species with lower IV values as compared to the community indicators. Nonetheless, Phytolacca latbenia, Pleurospermum stellatum, P. stylosum, Seseli libanotis, Torilis japonica, Vicia sativa, Vincetoxicum petrense, Corydalis carinata, Polygonatum verticillatum, Salix tetrasperma, Sida cordata, Thalictrum pedunculatum, Lindelofia sp., Spiraea vaccinifolia and Trachyspermum amii were found as the rare species with less IV values. Therophytic class dominated the life form spectrum, accounting for $43.69 \%$ of plant species, followed by nanophanerophytes $(19.42 \%)$. Nanophyllous leaf size class dominated the SCD community with $31.30 \%$ of species, followed by Microphyll (28.24\%) and Leptophyll (19.08\%). Moreover, one aphyllous plant species was also found in SCD community (Table 1). The most influential ecological variables that influenced the composition of SCD community were K (210-228 mg/kg), P (12.8 mg/kg), pH (5.2-6.9), and EC $\left(3.3 \mathrm{dsm}^{-1}\right)$, and loamy soil texture (Figure 3$)$, which were distributed on a slope angle of $25-85^{\circ}$ (Supplementary data Figures S1-S4).

\subsubsection{Indigofera-Cedrus-Pinus Community}

This plant community was recognized in 12 stands on the N-W aspect between altitudinal ranges of 1932.3-2437.8 m, which has 141 associated species (Table 1). Indigofera heterantha (10.16 IV), Cedrus deodara (5.75 IV) and Pinus wallichiana (5.66 IV) were recorded as the leading indicators of this plant community with the highest IV values. Other co- 
dominant species were Viburnum grandiflorum, Cynodon dactylon, Heracleum candicans, Bistorta amplexicaulis, Poa infirma, Isodon rugosus, Lathyrus aphaca, Prunella vulgaris, Plantago major, Juglans regia, Impatiens brachycentra, Pennisetum orientale, Euphrasia himalayica and Pimpinella stewartii. Nonetheless, rare species with lower IV values included Epilobium hirsutum, Helianthus annuus, Salvia nubicola, Epimedium elatum, Sonchus asper, Avena sativa, Conyza japonica, Portulaca oleracea, Prunus armeniaca, Alcea rosea, Bauhinia variegata, Cotoneaster acuminatus, Lotus corniculatus, Lindelofia sp., Cornus macrophylla and Lavatera cachemiriana. Therophytes dominated the life form spectra accounting $37.59 \%$ of all the species in the ICP community, followed by Hemicryptophytes (25.53\%), Nanophanerophytes (11.35\%), and geophytes $(9.22 \%)$. The nanophyllous class dominated the leaf size spectra with $31.21 \%$ of species, followed by Microphyll (26.95\%), and Leptophyll (17.02\%). Nonetheless, aphyllous species accounted for the least number of species in the ICP community (1.42\% of species, Table 1$)$. The strongest ecological variables that significantly influenced the composition of plant species of ICP community associates were $\mathrm{CaCO}_{3}(7.5 \mathrm{mg} / \mathrm{kg})$, humidity $(49.2-68.5 \%)$, and soil texture (silty loam) (Figure 3 and Supplementary data Figures S1-S4).

\subsubsection{Cedrus-Pinus-Parrotiopsis Community}

CPP community was recorded in 17 stands between the altitudinal ranges of 2292-3168 m. The highest number of species (197 species) were recorded in this plant community (Table 1 and Figure 2). Cedrus deodara (19.88 IV), Pinus wallichiana (17.26 IV) and Parrotiopsis jacquemontii (8.5 IV) were recognized as the topmost dominant species. Other co-dominant species with lower IV values than the community indicators included Cynodon dactylon, Oxalis corniculata, Clinopodium vulgare, Isodon rugosus, Indigofera heterantha, Impatiens bicolor, Fragaria nubicola, Geranium wallichianum and Clematis grata were. Moreover, species that were rarely recorded in this community were Rhynchosia pseudo-cajan, Sorbus tomentosa, Euphorbia helioscopia, Galium asparagifolium, Hyoscyamus niger, Silene conoidea, Poa infirma, Rosa webbiana, Galium aparine, Rumex nepalensis, Smilax glaucophylla, Spiranthes sinensis and Vicia sativa. Therophytes dominated the life form spectra with $42.31 \%$ of species, followed by Hemicryptophytes with $27.47 \%$ of species. The microphyllous and Nanophyllous classes dominated the leaf size spectra, accounting for 30.96\% of species, followed by Leptophyll $(17.77 \%)$ and mesophyll (14.72\%) (Table 1). Loamy and silty loamy texture, P (11.12 mg/kg), and $\mathrm{K}(214.6 \mathrm{mg} / \mathrm{kg})$ were all influencing variables for the CPP community (Figure 3 and Supplementary data Figures S1-S4). As a result, the highest species diversity was observed in this CPP community.

\subsubsection{Pinus-Viburnum-Cedrus Community}

The PVC community was recognized on the northern aspect between altitudinal ranges of 2568-3191 m in 7 stands with a total of 195 associated plant species. Pinus wallichianaViburnum grandiflorum-Cedrus deodara were recorded as the dominant species in this community with highest IV values of 17.98, 16.43, and 9.92, respectively. Other co-dominant and characteristic plant species were Abies pindrow, Arisaema jacquemontii, Juniperus squamata, Juniperus communis, Picea smithiana, Fragaria nubicola, Cynodon dactylon, Quercus incana, Urochloa panicoides and Bergenia stracheyi. Moreover, rare species of this PVC community with lower IV values included Impatiens bicolor, Lotus corniculatus, Rumex nepalensis, Epilobium latifolium, Helianthus annuus, Inula cuspidata, Platanus orientalis, Pleurospermum stylosum, Pteracanthus urticifolius and Swertia paniculata. Therophytes dominated the life form with $33.66 \%$ of species, followed by Hemicryptophytes with $30.69 \%$ of species, and Nanophanerophytes with $11.88 \%$ of species (Table 1). Nanophyllous dominated the leaf size spectra, accounting for $34.18 \%$ of plant species, followed by Microphyll (18.06\%) and Leptophyll (16.84\%) (Table 1). OM (2.12\%), K (215.7 mg/kg), P (11.9 mg/kg), and EC (2.12 dsm $\left.{ }^{-1}\right)$ were the most effective ecological variables that had a positive influence on the species diversity of the PVC community (Supplementary data Figures S1-S4). 


\subsubsection{Abies-Picea-Juniperus Community}

This community (APJ) was recorded at the middle altitudinal range (2874-3260 m) of the north-western aspect of the study area with 66 associated plant species (Table 1). The indicators of the APJ community are Abies pindrow (26.17 IV), Picea smithiana (23.77 IV), and Juniperus squamata (21.77 IV). Thymus linearis, Bistorta affinis, Bergenia stracheyi, Rheum australe, and Poa infirma are some of the herb layer's co-dominant species, while Juniperus communis and Cotoneaster microphyllus are the distinguishing species of the shrubby layer. Furthermore, Quercus incana and Pinus wallichiana are the major tree layer associates with the APJ community. The APJ community is characterised by a preference for the shade. In comparison to sub-alpine (JSJ) and alpine (SBR) communities, hill slopes get less direct sunlight. The shade effect was significantly influenced by the tree layer's larger canopy cover. Hemicryptophytes dominated the life form classes with $40.98 \%$ of species, followed by Therophytes $(29.51 \%)$, Chamaephytes, and Geophytes $(9.84 \%)$ each. The nanophyllous class dominated the leaf size spectra, accounting for $33.33 \%$ of plant species, followed by Microphyll (27.27\%) and Leptophyll (24.24\%) (Table 1). Low K (205.4 mg/kg) and low EC $\left(1.4 \mathrm{dsm}^{-1}\right)$ were the most significant ecological variables that played a vital role in the formation of the APJ community. Moreover, the APJ community was hosted by a clay-loamy soil texture (Supplementary data Figures S1-S4) with a low pH (Figure 3).

\subsubsection{Juniperus-Sibbaldia-Juniperus Community}

With a total of 40 associated species, this community (JSJ) was observed in six stands varying in altitude from 3250 to $3644 \mathrm{~m}$ (Table 1). The indicators of the JSJ community are shrubs, i.e., Juniperus squamata, Sibbaldia procumbens, Juniperus squamata. The tree layer was represented by the only species (Rhododendron arboreum). Other shrubby layer associates of the JSJ community includes Cotoneaster microphyllus, and Juniperus excelsa, while the herb layer associates were Bergenia stracheyi, Bistorta affinis, Caltha palustris, Dracocephalum nutans, Primula hazarica, Poa infirma and Rheum australe. Hemicryptophytes dominated the life form spectra, accounting for $56.82 \%$ of plant species, followed by Therophytes $(18.18 \%)$, Geophytes and Nanophanerophytes (11.36\%) each (Table 1$)$. The leaf size spectrum was dominated by Nanophyllous class (34.69\% of plant species), followed by Leptophyll (26.53\% of plant species), Microphyll (20.41\% of plant species) and Mesophyll $(14.29 \%$ of plant species). Low EC $\left(0.85 \mathrm{dsm}^{-1}\right)$, temperature $\left(7.4-13.8^{\circ} \mathrm{C}\right)$, WS $(2-3 \mathrm{~m} / \mathrm{s})$ and DP $(12.8-15.5)$ all had a significant impact on the JSJ community. As a result, these ecological variables constrain the species diversity of JSJ community (Supplementary data Figures S1-S4).

\subsubsection{Sibbaldia-Bergenia-Rheum Community}

This community (SBR) was identified at the higher altitudinal ranges (3199-3688 m) above the timber line at latitude $(\mathrm{N}=34.69472-34.79333)$ and longitude $(\mathrm{E}=73.60278-73.68639)$. The SBR community represents subalpine vegetation, having Sibbaldia procumbens (10.78 IV), Bergenia stracheyi (8.37 IV), and Rheum australe (7.75 IV) as the indicator species, for a total of 53 associated species. The herbaceous species dominated the vegetation, although some nanophanerophytes occur at comparatively lower altitudes, i.e., Juniperus squamata, J. communis, J. excelsa and Cotoneaster microphyllus. Nevertheless, other herbaceous codominants were Poa alpina, P. infirma, Bistorta affinis, and Primula hazarica. This subalpine community develops in between the timberline and alpine meadows, regardless of slope aspect, and overlaps with the alpine community (Poa-Bistorta-Primula) at most of the elevations. Hemicryptophytes dominated the life form spectra with $48 \%$ of species, followed by Therophytes (24\% of species) and chamaephytes (12\% of species). The Nanophyllous class dominated the leaf size spectra, accounting for $38 \%$ of all species, followed by Leptophyll (18\%) and microphyll (20\%) (Table 1). The altitude and WS (2.5-5 m/s) had a significant impact on this plant community. The indicators, as well as other associated species were also found to be temperature sensitive. The soil texture hosting the SBR community was mainly clay, with the lowest $\mathrm{K}(197-216.6 \mathrm{mg} / \mathrm{kg})$ and $\mathrm{pH}(4.8-5.8)$ values and maximum OM (0.98-2.28\%) concentration (Figure 3). Moreover, the SBR community was found to be 
negatively associated with ecological variables such as humidity, $\mathrm{CaCO}_{3}, \mathrm{HI}, \mathrm{WB}, \mathrm{BP}$, and slope angle (Supplementary data Figures S1, S3 and S4).

\subsubsection{Poa-Bistorta-Primula Community}

The Poa-Bistorta-Primula Community (PBP) was recognized as the highest altitudinal (3724-4278 m) alpine and cold desert plant community recorded at a latitude $(\mathrm{N}=34.69306-34.83861)$ and a longitude (E = 73.60750-73.69444). Poa alpina (17.32 IVI), Bistorta affinis (15.03 IV), and Primula rosea (9.07 IV) are the indicator species of PBP community. Other co-dominant species are Rheum australe, Bergenia stracheyi and Androsace hazarica. This plant community included a total of 39 species. However, tree and shrub layers (Phanerophytes and Nanophanerophytes) were entirely absent from these alpine meadows. Moreover, this alpine community (PBP) has a low species richness as compared to other plant communities (Figure 2 and Table 1). Extremely low temperatures are a hallmark of the growth period due to high elevation. Xeric conditions compounded such harsh environments, and a relatively short growth season was recorded from July to September. Hemicryptophytes contributed $53.85 \%$ of the species, followed by Therophytes (23.08\%), Chamaephytes $(12.82 \%)$, and Geophytes (10.26\%). Microphyll and Nanophyll classes dominated the leaf size spectra with $28.95 \%$ of species each, followed by Leptophyll (21.05\%) (Table 1). Higher altitude and WS (3.5-8 m/s), as well as low temperature had a strong impact on the indicators and other associates of PBP community. The soil texture hosting this community was sandy in nature (Figure 3), with the lowest K (196-206.9 mg/kg) and pH (4.9-5.6) and maximum OM (1.15-2.64\%) concentration. Furthermore, the PBP community was found to be negatively associated with ecological variables such as humidity, $\mathrm{CaCO}_{3}, \mathrm{HI}, \mathrm{WB}, \mathrm{BP}$, and slope angle (Supplementary data Figures S1-S4).

\subsection{Non-Metric Multidimensional Scaling (NMDS)}

All the data based on 354 plant species in 133 sampled stands were categorized into 12 plant communities using NMDS. Plant communities that are close together or on the same axis have a positive correlation, whereas communities that are far apart or on different axes have a negative correlation. The Poa-Bistorta-Primula, Sibbaldia-Bergenia-Rheum, and Juniperus-Sibbaldia-Juniperus communities, for example, had a positive association with one another but negatively correlated with the Indigofera-Juglans-Isodon, and Indigofera-CedrusPinus communities (Figure 4). All these relationships could be attributed to patterns in the variables of their host environment. For example, the former plant communities were found at elevations of 3724-4278 m, 3199-3688 m, and 3250-3644 m, respectively, while the latter plant communities were found at lower elevations (1597-2456 m and 1932.3-2437.8 m), respectively. Moreover, four stands (S38, S39, S40, S41 and S42) are correlated with each other and shaped the SSI community. The PBP community identified in 13 stands can be seen far apart from the other plant communities. Only the three most representative plant species for each community are plotted. 


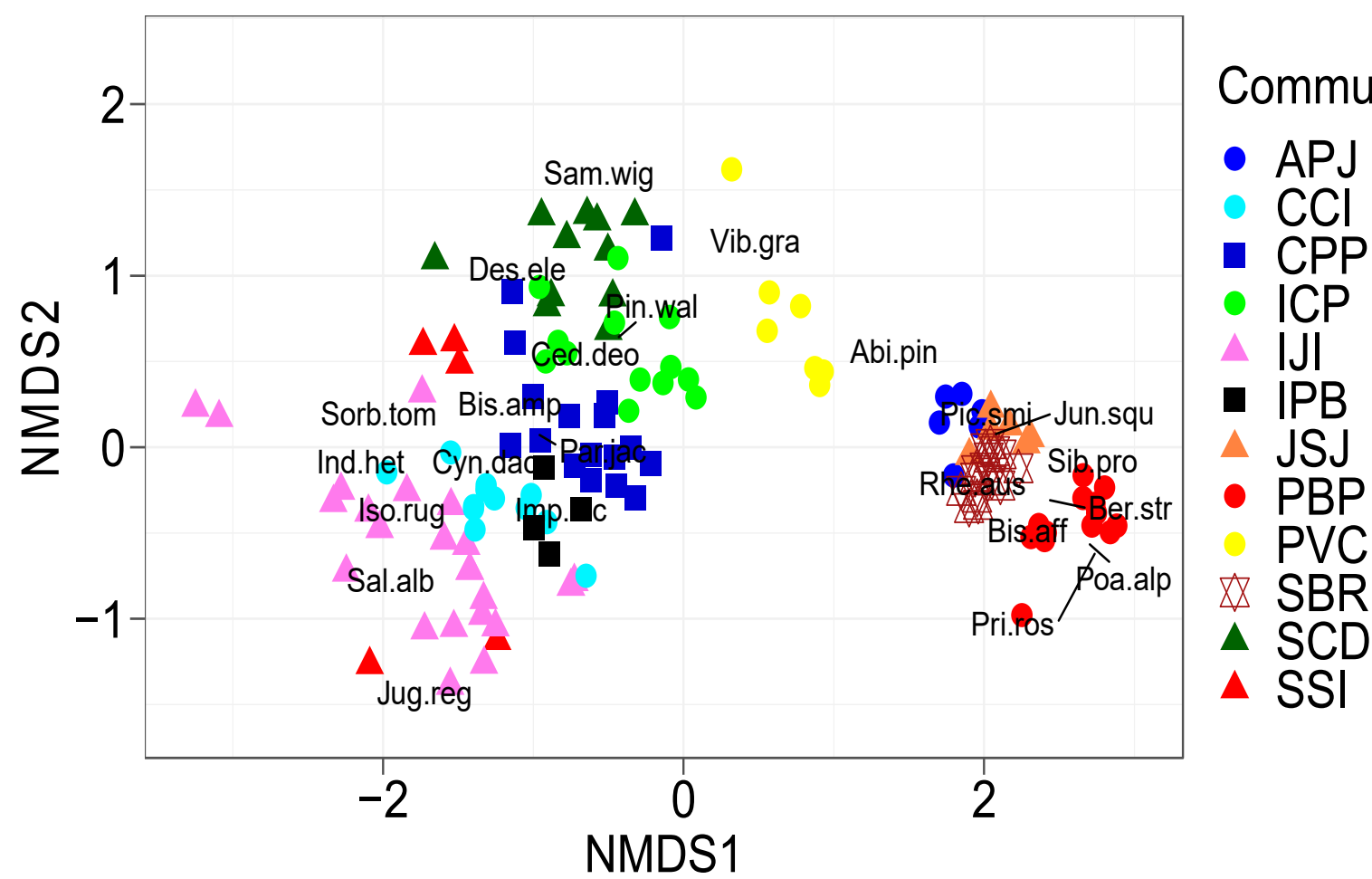

Figure 4. NMDS ordination is based on plant species that are in association with sampled stands and grouped into communities Plant communities that are close together or on the same axis and have a positive correlation. Only the three most representative plant species for each community are plotted. Some species are present in different communities and due to that, the total number of species are not 36.

\subsection{Canonical Correspondence Analysis (CCA)}

The CCA and variation partitioning tests showed that the total inertia results of CCA was 8.626, where our final variables (Altitude, Slope ES, Slope SE, Slope SW, Slope WN, EC, heat index) together explained $22.6 \%$ of variation. CCA model was significant $\left(\chi^{2}=1.951\right.$; pseudo-F value $=4.529 ; p<0.001$ ). For the 8 explanatory variables, we tested simple term effects. Simple term effects showed that all variables were significant $\left(\chi^{2}\right.$ range $=0.104$ 0.785 ; pseudo-F value [range] $=1.93-14.59 ; p<0.006$; Table 1 ). Finally, the two first axis were also highly significant $(p<0.001)$. Table 2 displays the significance level of the testing results regarding the influence of environmental variables on the vegetation of the Manoor Valley. The PBP, SBR and JSJ plant communities revealed positive association with altitude (Supplementary data Figures S1-S4). All these plant communities were found at the higher altitudes (3724-4278 m, 3199-3688 m, and 3250-3644 m), respectively. The slope angle, on the other hand, has a negative relationship with altitude. The IJI and ICP plant communities are in positive association with slope angle. This strong influential association might be due to the occurrence of these plant communities in the lower (1597-2456 m) and middle (1932.3-2437.8 $\mathrm{m}$ ) altitudinal ranges.

Table 2. Detailed numerical results of variations partitioning (partial CCA) for groups of variables.

\begin{tabular}{ccccccccc}
\hline \multirow{2}{*}{ Gradient Class } & \multirow{2}{*}{ Variation (adj) } & \multirow{2}{*}{ \% of Explained } & \multicolumn{2}{c}{ Eigen Values } & \multicolumn{2}{c}{$\boldsymbol{p}$} \\
\cline { 4 - 7 } & & & Axis 1 & Axis 2 & Axis 3 & Axis 4 & \\
\hline Edaphic & 9.8 & 18.7 & 0.6211 & 0.1887 & 0.1135 & 0.0904 & 2.1 & 0.002 \\
\hline Climatic & 9.8 & 13.9 & 0.7210 & 0.1138 & 0.0841 & 0.0546 & 3.4 & 0.002 \\
\hline Physio-graphic & 18.1 & 25.5 & 0.7641 & 0.2903 & 0.2176 & 0.1624 & 3.4 & 0.002 \\
\hline Aspect & 9.1 & 15.3 & 0.4280 & 0.1675 & 0.1417 & 0.1206 & 2.5 & 0.002 \\
\hline
\end{tabular}




\section{Discussion}

Plant species are distributed in diverse types of habitats, forming different communities driven by different sets of environmental variables [6]. The aspect stimulates habitat diversification and promotes micro-environmental variation in the vegetation structure [36,37]. As a result, the composition of different units is observed as a reflection of changing habitat settings along environmental variables [38]. Here, we used different multivariate approaches to assess potential plant communities along an altitudinal gradient and their association with different environmental drivers. Our study documented 354 plant species belonging to 93 families. The current research area is located at the elevations ranging from $1580 \mathrm{~m}$ to $4278 \mathrm{~m}$, with varying environmental conditions that are reflected in a rich and diverse flora. Our results showed that at high altitudes, species richness was reduced, whereas an increase in soil nutrients was linked to progression in vegetation indicators. We also found different clusters of species with similar habitats. Our study clearly shows how altitudinal variables can cluster different plant communities according to different microclimates.

In the current vegetational sampling of a remote valley (Manoor Valley, Himalaya), 12 major plant communities were established by TWINSPAN from the lower ranges to the alpine meadows. The CPP communities (197 species) in the middle altitudinal habitats (2292-3168 m) have the most plant species. Ordination methods have commonly been used to show species distribution and community structure along ecological variables [98,99]. Similarly, a researcher investigated the vegetation of the western Himalayas and identified five distinct communities, the most abundant of which were found on north-facing slopes at middle altitudes, where the moisture levels were highest [6]. Thirteen major groups were identified in the vegetation of Kammanassie areas using the TWINSPAN classification [100]. These results, along with ours, show evidence that elevational variables are suitable places to evaluate how changes in environmental variables drive plant community structure and diversity. In addition, these results also show that multivariate approaches are powerful tools for community analysis [43] and can be considered in new ecological studies as statistical methods.

As the study area is in the Himalayan belt, the vegetation was primarily of a SinoJapanese nature. The plant communities were classified based upon climatic (i.e., temperature, $\mathrm{HI}, \mathrm{DP}, \mathrm{WB}, \mathrm{BP}$, and WS), edaphic (i.e., soil $\mathrm{pH}, \mathrm{EC}, \mathrm{OM}, \mathrm{P}, \mathrm{K}, \mathrm{CaCO}_{3}$, soil texture), and topographic variables (i.e., altitude, altitudinal density, latitude, longitude, slope angle, different exposures, and aspects). The vegetation was classified into different communities/associations [101,102] represented by dominant species based on their importance values [20,103]. At lower elevational ranges (1580.8-2456 m), the plant communities with dominant species were Salix alba, Sorbaria tometosa, and Impatiens bicolor (SSI), Indigofera heterantha, Juglans regia, and Isodon rugosus (IJI), Cedrus deodara, Cynodon dactylon, and Isodon rugosus (CCI), Indigofera heterantha, Parrotiopsis jacquemontii, and Bistorta amplexicaule (IPB), and Sambucus weightiana, Cedrus deodara, and Desmodium elegans (SCD) respectively. Similar indicators were recorded by other researchers during a field survey in the Himalayas of Pakistan [104].

The vegetation in the upper altitudinal ranges includes Pinus wallichiana, Abies pindrow, Indigofera heterantha and Viburnum grandiflorum, which are the representatives of moist temperate forests. These plant species are the temperate zone representatives $[30,39,41,105,106]$. These plant associations were shaped by the impact of various environmental gradients. Ecosystems respond to numerous simultaneous changes in the environment as these variations differ the diversity and distribution of communities [107,108]. Vegetation in distributions more closely resembles the changes in soil characteristics [109-111]. Our results revealed that soil characteristics such as $\mathrm{EC}, \mathrm{pH}$, soil texture, OM, K and $\mathrm{P}$ had a great impact on plant community distribution and association. Soil variables, altitude, latitude, slope aspect and angle also had a strong influence on species richness, as previously reported by [112].

Dissimilar plant communities were described as those with less than $65 \%$ similarity $[113,114]$. The communities' similarities were due to shrubs, trees, and perennial plants, 
while the communities' dissimilarities were due to Therophytes. The maximum similarity index was noted between SBR and JSJ communities (55.53\%), followed by JSJ and APJ communities with $39.71 \%$ of similarity. The highest similarity between communities may be due to similar environmental conditions [30], which leads to changes in the species' habitat. The highest dissimilarity was observed between PBP and IPB communities, JSJ and SSI communities (99.94\% each), followed by IJI and PBP communities $(99.92 \%)$, SSI and PBP communities $(99.91 \%)$. These results follow the findings of [6,53]. Maximum dissimilarity between communities might be due to wide altitudinal variation among communities [30,115], which represents the presence of different set of species adapted to different set of climatic variables [112,116-118].

\section{Conclusions}

To the best of our knowledge, this is the only valley within the Himalayas of Pakistan that has never been explored before, due to its harsh terrain and geographical location. The current study revealed that the sampled area has rich species diversity. The study provides the first ever detailed insights into the spatial distribution and vegetation mapping in response to environmental variables in the study area. The flora of the Manoor Valley consists of 354 plant species belonging to 93 families, distributed into a total of 12 major plant communities, from the lowest altitude to the alpine zones. The Cedrus-Pinus-Parrotiopsis community resided at the middle altitudinal ranges (2292-3168 m) was recorded with highest number of associates (197 species). Our study clearly shows how altitudinal variables can cluster different plant communities according to different microclimates, which can be a proxy for future studies evaluating the impacts of climate change on plant communities. Studies such as ours are paramount to better understand how environmental factors influence ecological and evolutionary aspects.

Supplementary Materials: The following supporting information can be downloaded at: https: / /www.mdpi.com/article/10.3390/plants11010087/s1. Figure S1: Canonical correspondence analysis: (a) \& (c) the contour plot shows the count of species at each axis, (b) Distribution of plant species along the edaphic variables, (d). Distribution of plant species along the climatic variables. Figure S2: Canonical correspondence analysis: (a). the contour plot shows the count of species at each axis, (b). Distribution of plant species along the slope aspects. Figure S3: Canonical correspondence analysis: (a) Distribution of stands along the edaphic variables, (b) and (c) Van Dobben circles show the correlation of species in association to edaphic variables and among them, i.e., red circle shows the positive and blue indicates the negative correlation. Figure S4: Canonical correspondence analysis: (a) Association of sampling sites along the climatic variables, (b). Association of sampling sites along the slope aspects.

Author Contributions: I.U.R.: Conceptualization, Methodology, Software, Data curation, WritingOriginal draft preparation. A.A.: Supervision, Visualization. Z.I.: Supervision, Methodology, Validation. M.N.A., A.-B.F.A.-A., A.A.A. and E.F.A.: Resources, helped in revision, Validation. N.A., S.S., M.A.K., U.K., F.I. and S.M.: helped in revision, Reviewing and Editing. E.S.C.: Reviewing and Editing, Validation. All authors have read and agreed to the published version of the manuscript.

Funding: The authors would like to extend their sincere appreciation to the Researchers Supporting Project Number (RSP-2021/134), King Saud University, Riyadh, Saudi Arabia.

Acknowledgments: The first author is thankful to Bougand Bassuner (Lehmann Building, Missouri Botanical Garden, St. Louis, MO, USA) for providing support and guidance using ArcGIS software. The authors would like to extend their sincere appreciation to the Researchers Supporting Project Number (RSP-2021/134), King Saud University, Riyadh, Saudi Arabia.

Conflicts of Interest: The authors declare no conflict of interest.

\section{References}

1. Capelo, J. Using species abundance and phylogeny conjointly to approach vegetation classification: A case study on Macaronesia's woody vegetation. J. Veg. Sci. 2020, 31, 616-633. [CrossRef]

2. Czortek, P.; Orczewska, A.; Dyderski, M.K. Niche differentiation, competition or habitat filtering? Mechanisms explaining co-occurrence of plant species on wet meadows of high conservation value. J. Veg. Sci. 2021, 32, e12983. [CrossRef] 
3. Černý, T.; Kopecký, M.; Petř́ik, P.; Song, J.; Šrůtek, M.; Valachovič, M.; Altman, J.; Doležal, J. Classification of K orean forests: Patterns along geographic and environmental gradients. Appl. Veg. Sci. 2015, 18, 5-22. [CrossRef]

4. Rahman, I.U. Ecophysiological Plasticity and Ethnobotanical Studies in Manoor Area, Kaghan Valley, Pakistan. Ph.D. Thesis, Hazara University, Mansehra, Pakistan, 2020.

5. Haq, F. Phytosociological Attributes of Different Vegetational Zones of Nandiar Khuwar Catchment Area. Ph.D. Thesis, Hazara University, Mansehra, Pakistan, 2015.

6. Khan, S.M. Plant Communities and Vegetation Ecosystem Services in the Naran Valley, Western Himalaya. Ph.D. Thesis, University of Leicester, Leicester, UK, 2012.

7. Loreau, M.; Naeem, S.; Inchausti, P.; Bengtsson, J.; Grime, J.P.; Hector, A.; Hooper, D.U.; Huston, M.A.; Raffaelli, D.; Schmid, B. Biodiversity and ecosystem functioning: Current knowledge and future challenges. Science 2001, 294, 804-808. [CrossRef] [PubMed]

8. Hamilton, A.J. Species diversity or biodiversity? J. Environ. Manage. 2005, 75, 89-92. [CrossRef] [PubMed]

9. Chiarucci, A.; Bacaro, G.; Scheiner, S.M. Old and new challenges in using species diversity for assessing biodiversity. Philos. Trans. R. Soc. B Biol. Sci. 2011, 366, 2426-2437. [CrossRef]

10. Field, R.; Hawkins, B.A.; Cornell, H.V.; Currie, D.J.; Diniz-Filho, J.A.F.; Guégan, J.-F.; Kaufman, D.M.; Kerr, J.T.; Mittelbach, G.G.; Oberdorff, T.; et al. Spatial species-richness gradients across scales: A meta-analysis. J. Biogeogr. 2009, 36, 132-147. [CrossRef]

11. Kullman, L. Alpine flora dynamics-A critical review of responses to climate change in the Swedish Scandes since the early 1950s. Nord. J. Bot. 2010, 28, 398-408. [CrossRef]

12. Jabis, M.D. Climate Change Impacts in Alpine Plant Communities. Ph.D. Thesis, UC Berkeley, Berkeley, CA, USA, 2018.

13. Malanson, G.P.; Nelson, E.L.; Zimmerman, D.L.; Fagre, D.B. Alpine plant community diversity in species-area relations at fine scale. Arctic, Antarct. Alp. Res. 2020, 52, 41-46. [CrossRef]

14. Dvorský, M.; Doležal, J.; De Bello, F.; Klimešová, J.; Klimeš, L. Vegetation types of East Ladakh: Species and growth form composition along main environmental gradients. Appl. Veg. Sci. 2011, 14, 132-147. [CrossRef]

15. Pauli, H.; Gottfried, M.; Dullinger, S.; Abdaladze, O.; Akhalkatsi, M.; Alonso, J.L.B.; Coldea, G.; Dick, J.; Erschbamer, B.; Calzado, R.F.; et al. Recent Plant Diversity Changes on Europe's Mountain Summits. Science 2012, 336, 353-355. [CrossRef]

16. Steinbauer, M.J.; Grytnes, J.-A.; Jurasinski, G.; Kulonen, A.; Lenoir, J.; Pauli, H.; Rixen, C.; Winkler, M.; Bardy-Durchhalter, M.; Barni, E.; et al. Accelerated increase in plant species richness on mountain summits is linked to warming. Nature 2018, 556, 231-234. [CrossRef] [PubMed]

17. Adair, K.L.; Lindgreen, S.; Poole, A.M.; Young, L.M.; Bernard-Verdier, M.; Wardle, D.A.; Tylianakis, J.M. Above and belowground community strategies respond to different global change drivers. Sci. Rep. 2019, 9, 1-11. [CrossRef] [PubMed]

18. Brun, P.; Zimmermann, N.E.; Graham, C.H.; Lavergne, S.; Pellissier, L.; Münkemüller, T.; Thuiller, W. The productivity-biodiversity relationship varies across diversity dimensions. Nat. Commun. 2019, 10,1-11. [CrossRef]

19. Curtis, J.T.; McIntosh, R. The interrelations of certain analytic and synthetic phytosociological characters. Ecology 1950, 31, 434-455 [CrossRef]

20. Dufrêne, M.; Legendre, P. Species assemblages and indicator species: The need for a flexible asymmetrical approach. Ecol. Monogr. 1997, 67, 345-366. [CrossRef]

21. Paudel, P.K.; Sipos, J.; Brodie, J.F. Threatened species richness along a Himalayan elevational gradient: Quantifying the influences of human population density, range size, and geometric constraints. BMC Ecol. 2018, 18, 1-8. [CrossRef]

22. Hussain, F.; Shah, S.M.; Badshah, L.; Durrani, M.J. Diversity and ecological characteristics of flora of Mastuj valley, district Chitral, Hindukush range, Pakistan. Pak. J. Bot 2015, 47, 495-510.

23. Rahman, I.U.; Afzal, A.; Iqbal, Z.; Ijaz, F.; Ali, N.; Asif, M.; Alam, J.; Majid, A.; Hart, R.; Bussmann, R.W. First insights into the floristic diversity, biological spectra and phenology of Manoor valley, Pakistan. Pakistan J. Bot. 2018, 50, 1113-1124.

24. Rahman, I.U.; Hart, R.; Afzal, A.; Iqbal, Z.; Abdallah, E.F.; Alqarawi, A.A.; Ijaz, F.; Ali, N.; Kausar, R.; Muzammil, S.; et al. Phenological plasticity in Berberis lycium Royle along temporal and altitudinal gradients. Appl. Ecol. Environ. Res. 2019, 17, 331-341. [CrossRef]

25. Cañadas, E.M.; Fenu, G.; Peñas, J.; Lorite, J.; Mattana, E.; Bacchetta, G. Hotspots within hotspots: Endemic plant richness, environmental drivers, and implications for conservation. Biol. Conserv. 2014, 170, 282-291. [CrossRef]

26. Noroozi, J.; Talebi, A.; Doostmohammadi, M.; Rumpf, S.B.; Linder, H.P.; Schneeweiss, G.M. Hotspots within a global biodiversity hotspot-Areas of endemism are associated with high mountain ranges. Sci. Rep. 2018, 8, 10345. [CrossRef] [PubMed]

27. Kidane, Y.O.; Steinbauer, M.J.; Beierkuhnlein, C. Dead end for endemic plant species? A biodiversity hotspot under pressure. Glob. Ecol. Conserv. 2019, 19, e00670. [CrossRef]

28. Noroozi, J.; Naqinezhad, A.; Talebi, A.; Doostmohammadi, M.; Plutzar, C.; Rumpf, S.B.; Asgarpour, Z.; Schneeweiss, G.M. Hotspots of vascular plant endemism in a global biodiversity hotspot in Southwest Asia suffer from significant conservation gaps. Biol. Conserv. 2019, 237, 299-307. [CrossRef]

29. Givnish, T.J. On the causes of gradients in tropical tree diversity. J. Ecol. 1999, 87, 193-210. [CrossRef]

30. Iqbal, Z.; Zeb, A.; Abd_Allah, E.F.; Rahman, I.U.; Khan, S.M.; Ali, N.; Ijaz, F.; Anwar, Y.; Muzammil, S.; Alqarawi, A.A.; et al. Ecological assessment of plant communities along the edaphic and topographic gradients of biha valley, District Swat, Pakistan. Appl. Ecol. Environ. Res. 2018, 16. [CrossRef]

31. Klanderud, K.; Birks, H.J.B. Recent increases in species richness and shifts in altitudinal distributions of Norwegian mountain plants. The Holocene 2003, 13, 1-6. [CrossRef] 
32. Odland, A.; Birks, H.J.B. The altitudinal gradient of vascular plant richness in Aurland, western Norway. Ecography (Cop.). 1999, 22, 548-566. [CrossRef]

33. Weckström, J.; Korhola, A. Patterns in the distribution, composition and diversity of diatom assemblages in relation to ecoclimatic factors in Arctic Lapland. J. Biogeogr. 2001, 28, 31-45. [CrossRef]

34. Heywood, V.H.; Watson, R.T. Global Biodiversity Assessment; Cambridge University Press: Cambridge, UK, 1995 ; Volume 1140.

35. McGrady-Steed, J.; Morin, P.J. Biodiversity, density compensation, and the dynamics of populations and functional groups. Ecology 2000, 81, 361-373. [CrossRef]

36. Luo, Z.; Tang, S.; Li, C.; Fang, H.; Hu, H.; Yang, J.; Ding, J.; Jiang, Z. Environmental effects on vertebrate species richness: Testing the energy, environmental stability and habitat heterogeneity hypotheses. PLoS ONE 2012, 7, e35514. [CrossRef] [PubMed]

37. Yang, Z.; Liu, X.; Zhou, M.; Ai, D.; Wang, G.; Wang, Y.; Chu, C.; Lundholm, J.T. The effect of environmental heterogeneity on species richness depends on community position along the environmental gradient. Sci. Rep. 2015, 5, 15723. [CrossRef] [PubMed]

38. Smith, M.; Facelli, J.; Cavagnaro, T. Interactions between soil properties, soil microbes and plants in remnant-grassland and old-field areas: A reciprocal transplant approach. Plant Soil 2018, 433, 127-145. [CrossRef]

39. Champion, S.H.; Seth, S.K.; Khattak, G.M. Forest Types of Pakistan; Pakistan Forest Institute: Peshawar, Pakistan, 1965.

40. Beg, A.R. Wildlife Habitats of Pakistan; Pakistan Forest Institute: Peshawar, Pakistan, 1975.

41. Ahmed, M.; Husain, T.; Sheikh, A.H.; Hussain, S.S.; Siddiqui, M.F. Phytosociology and structure of Himalayan forests from different climatic zones of Pakistan. Pakistan J. Bot. 2006, 38, 361.

42. Rahman, I.-U.; Afzal, A.; Abd_Allah, E.F.; Iqbal, Z.; Alqarawi, A.A.; Hashem, A.; Calixto, E.S.; Ali, N.; Asmarayani, R. Composition of plant communities driven by environmental gradients in alpine pastures and cold desert of northwestern Himalaya, Pakistan. Pakistan J. Bot. 2021, 53, 655-664. [CrossRef]

43. Rahman, I.U.; Afzal, A.; Iqbal, Z.; Bussmann, R.W.; Alsamadany, H.; Calixto, E.S.; Shah, G.M.; Kausar, R.; Shah, M.; Ali, N.; et al. Ecological gradients hosting plant communities in Himalayan subalpine pastures: Application of multivariate approaches to identify indicator species. Ecol. Inform. 2020, 60, 101162. [CrossRef]

44. Rahman, I.U.; Afzal, A.; Iqbal, Z.; Hart, R.; Abd_Allah, E.F.; Alqarawi, A.A.; Alsubeie, M.S.; Calixto, E.S.; Ijaz, F.; Ali, N.; et al Response of plant physiological attributes to altitudinal gradient: Plant adaptation to temperature variation in the Himalayan region. Sci. Total Environ. 2020, 706, 135714. [CrossRef]

45. Rahman, I.U.; Calixto, E.S.; Afzal, A.; Iqbal, Z.; Ali, N.; Ijaz, F.; Shah, M.; Hakeem, K.R. Advanced multivariate and computational approaches in agricultural studies. In Essentials of Bioinformatics, Volume II: In Silico Life Sciences: Medicine; Shaik, N.A., Hakeem, K.R., Banaganapall, B., Elango, R., Eds.; Springer International Publishing: Cham, Switzerland, 2019; pp. 93-102. ISBN 9783030193171.

46. Gehlhausen, S.M.; Schwartz, M.W.; Augspurger, C.K. Vegetation and microclimatic edge effects in two mixed-mesophytic forest fragments. Plant Ecol. 2000, 147, 21-35. [CrossRef]

47. Sánchez-Rojas, G.; Gallina, S. Factors affecting habitat use by mule deer (Odocoileus hemionus) in the central part of the Chihuahuan Desert, Mexico: An assessment with univariate and multivariate methods. Ethol. Ecol. Evol. 2000, 12, 405-417. [CrossRef]

48. Kleyer, M.; Dray, S.; Bello, F.; Lepš, J.; Pakeman, R.J.; Strauss, B.; Thuiller, W.; Lavorel, S. Assessing species and community functional responses to environmental gradients: Which multivariate methods? J. Veg. Sci. 2012, 23, 805-821. [CrossRef]

49. Gauch, H.G.; Gauch, H.G., Jr. Multivariate Analysis in Community Ecology; Cambridge University Press: Cambridge, UK, 1982; ISBN 0521282403.

50. Rahman, I.U.; Afzal, A.; Iqbal, Z.; Abd-Allah, E.F.; Alqarawi, A.A.; Calixto, E.S.; Ali, N.; Ijaz, F.; Kausar, R.; Alsubeie, M.S.; et al. Role of multivariate approaches in floristic diversity of Manoor valley (Himalayan region) Pakistan. Appl. Ecol. Environ. Res. 2019, 17, 1475-1498. [CrossRef]

51. Rahman, I.U.; Ijaz, F.; Afzal, A.; Iqbal, Z.; Ali, N.; Khan, S.M. Contributions to the phytotherapies of digestive disorders: Traditional knowledge and cultural drivers of Manoor Valley, Northern Pakistan. J. Ethnopharmacol. 2016, 192, 30-52. [CrossRef] [PubMed]

52. Clift, P.D.; Giosan, L.; Blusztajn, J.; Campbell, I.H.; Allen, C.; Pringle, M.; Tabrez, A.R.; Danish, M.; Rabbani, M.M.; Alizai, A Holocene erosion of the Lesser Himalaya triggered by intensified summer monsoon. Geology 2008, 36, 79-82. [CrossRef]

53. Haq, F.; Ahmad, H.; Iqbal, Z.; Alam, M.; Aksoy, A. Multivariate approach to the classification and ordination of the forest ecosystem of Nandiar valley western Himalayas. Ecol. Indic. 2017, 80, 232-241. [CrossRef]

54. Buckland, S.T.; Anderson, D.R.; Burnham, K.P.; Laake, J.L.; Borchers, D.L.; Thomas, L. Introduction to Distance Sampling: Estimating Abundance of Biological Populations; Oxford Univ. Press: Oxford, UK, 2001.

55. Buckland, S.T.; Anderson, D.R.; Burnham, K.P.; Laake, J.L.; Borchers, D.L.; Thomas, L. Advanced Distance Sampling; Oxford University Press: Oxford, UK, 2004; Volume 2.

56. Buckland, S.T.; Newman, K.B.; Fernández, C.; Thomas, L.; Harwood, J. Embedding population dynamics models in inference Stat. Sci. 2007, 22, 44-58. [CrossRef]

57. Anderson, D.R.; Burnham, K.P.; Laake, J.L. Distance Sampling: Estimating Abundance of Biological Populations; Chapman \&Hall: London, UK, 1993.

58. Le Moullec, M.; Pedersen, Å.Ø.; Yoccoz, N.G.; Aanes, R.; Tufto, J.; Hansen, B.B. Ungulate population monitoring in an open tundra landscape: Distance sampling versus total counts. Wildl. Biol. 2017, 2017, 4. [CrossRef]

59. Kent, M. Vegetation Description and Data Analysis: A Practical Approach, 2nd ed.; John Wiley \& Sons: Hoboken, NJ, USA, 2012; ISBN 1119962390. 
60. Qadir, S.A.; Qureshi, S.Z.; Ahmed, M.A. A phytosociological survey of the Karachi University Campus. Vegetatio 1966, 13, 339-362. [CrossRef]

61. Rahman, M.M.; Mahmud, M.A.A.; Shahidullah, M.; Nath, T.K.; Jashimuddin, M. The competitiveness of the phytosociological attributes of the protected areas in Bangladesh with that in the other tropical countries. J. Sustain. For. 2016, 35, 431-450. [CrossRef]

62. Curtis, J.T. The Vegetation of Wisconsin: An Ordination of Plant Communities; University of Wisconsin Press: Madison, WI, USA, 1959; ISBN 0299019438.

63. Son, H.-J.; Park, S.-H.; Lee, D.-H.; Song, J.-H.; Park, H.-W.; Park, W.-G. Growing environment characteristics and vegetation structure of Vaccinium Oldhamii Miq. native habitats in Korea. For. Sci. Technol. 2019, 15, 33-43. [CrossRef]

64. Tian, Z.; Li, H.; Li, W.; Gan, X.; Zhang, X.; Fan, Z. Structural characteristics and niches of dominant tree populations in Tetracentron sinense communities: Implications for conservation. Bot. Sci. 2018, 96, 157-167. [CrossRef]

65. Lou, Y.; Pan, Y.; Gao, C.; Jiang, M.; Lu, X.; Xu, Y.J. Response of plant height, species richness and aboveground biomass to flooding gradient along vegetation zones in floodplain wetlands, Northeast China. PLoS ONE 2016, 11, e0153972. [CrossRef]

66. Song, J.H.; Cheong, E.J.; Kim, H.; Kim, M.S.; Kim, S.H. Variation of morphological characteristics and anthocyanin contents from fruit of Vaccinium oldhamii in Korea. J. Korean Soc. For. Sci. 2015, 104, 193-197. [CrossRef]

67. Raunkiaer, C. The Life Forms of Plants and Statistical Plant Geography; Being the Collected Papers of C. Raunkiaer; Clarendon Press: Oxford, UK, 1934.

68. Ijaz, F. Biodiversity and Traditional uses of Plants of Sarban Hills, Abbottabad. Ph.D. Thesis, Hazara University, Manehra, Pakistan, 2014.

69. Ijaz, F.; Rahman, I.; Iqbal, Z.; Alam, J.; Ali, N.; Khan, S. Ethno-ecology of the healing forests of Sarban Hills, Abbottabad, Pakistan: An economic and medicinal appraisal. In Plant and Human Health; Ozturk, K.R.H., Ed.; Springer International Publishing AG: Berlin/Heidelberg, Germany, 2018; pp. 675-706.

70. Nasir, E.; Ali, S.I. Flora West of Pakistan.; National Herbarium: Karachi, Pakistan, 1971.

71. Ali, S.I.; Nasir, Y.J. Flora of Pakistan; Department of Botany, University of Karachi, Karachi and National Herbarium: Islamabad, Pakistan, 1989.

72. Ali, S.I.; Qaiser, M. Flora of Pakistan; Department of Botany, University of Karachi: Karachi, Pakistan, 1995.

73. Haq, F.; Ahmad, H.; Iqbal, Z. Vegetation description and phytoclimatic gradients of subtropical forests of Nandiar Khuwar catchment District Battagram. Pakistan J. Bot. 2015, 47, 1399-1405.

74. Ravindranath, N.H.; Ostwald, M. Carbon Inventory Methods: Handbook for Greenhouse Gas Inventory, Carbon Mitigation and Roundwood Production Projects; Springer International Publishing AG: Berlin/Heidelberg, Germany, 2007.

75. Mc Lean, E.O. Soil $p H$ and Lime requirement. $n$ Methods of Soil Analysis Part 2 Chemical and Microbiological Properties; Page, A.L., Miller, R.H., Keeney, D.R., Eds.; American Society of Agronomy, Inc. Soil Science Society of America, Inc.: Madison, WI, USA, 1982; pp. 199-223.

76. Wilson, M.J.; Bayley, S.E. Use of single versus multiple biotic communities as indicators of biological integrity in northern prairie wetlands. Ecol. Indic. 2012, 20, 187-195. [CrossRef]

77. Nelson, D.W.; Sommers, L.E. Total carbon, organic carbon, and organic matter. In Methods ofSoil Analysis. Part 3. Chemical Method; Sparks, D.L., Page, A.L., Helmke, P.A., Loeppert, R.H., Soltanpour, P.N., Tabatabai, M.A., Johnston, C.T., Summer, M.E., Eds.; Soil Science Society of America and American Society of Agronomy: Madison, WI, USA, 1996; pp. 961-1010.

78. Paul, A.E.; Berry, E.H. The Kjeldahl nitrogen method and its modifications. J. Assoc. Off. Agric. Chem. 1921, 5, 108-132. [CrossRef]

79. Soltanpour, P.N.; Workman, S. Modification of the NH4 HCO3-DTPA soil test to omit carbon black. Commun. Soil Sci. Plant Anal. 1979, 10, 1411-1420. [CrossRef]

80. Soltanpour, P.N. Determination of nutrient availability and elemental toxicity by AB-DTPA soil test and ICPS. In Advances in Soil Science; Springer: New York, NY, USA, 1991; pp. 165-190.

81. Rahman, I.U.; Afzal, A.; Iqbal, Z.; Ijaz, F.; Khan, S.M.; Khan, S.A.; Shah, A.H.; Khan, K.; Ali, N. Influence of different nutrients application in nutrient deficient soil on growth and yield of onion. Bangladesh J. Bot. 2015, 44, 613-619. [CrossRef]

82. Rahman, I.U.; Ijaz, F.; Afzal, A.; Iqbal, Z. Effect of foliar application of plant mineral nutrients on the growth and yield attributes of chickpea (Cicer arietinum L.) Under nutrient deficient soil conditions. Bangladesh J. Bot. 2017, 46, 111-118.

83. Gilliam, F.S.; Saunders, N.E. Making more sense of the order: A review of Canoco for Windows 4.5, PC-ORD version 4 and SYN-TAX 2000. J. Veg. Sci. 2003, 14, 297-304. [CrossRef]

84. Šmilauer, P.; Lepš, J. Multivariate Analysis of Ecological Data Using CANOCO, 2nd ed.; Cambridge University Press: Cambridge, UK, 2014.

85. Mayor, J.R.; Sanders, N.J.; Classen, A.T.; Bardgett, R.D.; Clément, J.C.; Fajardo, A.; Lavorel, S.; Sundqvist, M.K.; Bahn, M.; Chisholm, C.; et al. Elevation alters ecosystem properties across temperate treelines globally. Nature 2017, 542, 91-95. [CrossRef]

86. Knapp, A.K.; Fay, P.A.; Blair, J.M.; Collins, S.L.; Smith, M.D.; Carlisle, J.D.; Harper, C.W.; Danner, B.T.; Lett, M.S.; McCarron, J.K. Rainfall variability, carbon cycling, and plant species diversity in a mesic grassland. Science 2002, 298, 2202-2205. [CrossRef] [PubMed]

87. McCune, B. PC-ORD: An integrated system for multivariate analysis of ecological data. Abstr. Bot. 1986, 10, $221-225$.

88. Rahman, I.U.; Afzal, A.; Iqbal, Z.; Hashem, A.; Al-Arjani, A.-B.F.; Alqarawi, A.A.; Abd_Allah, E.F.; Abdalla, M.; Calixto, E.S.; Sakhi, S. Species Distribution Pattern and Their Contribution in Plant Community Assembly in Response to Ecological Gradients of the Ecotonal Zone in the Himalayan Region. Plants 2021, 10, 2372. [CrossRef] 
89. Terzi, M.; Bogdanović, S.; D'Amico, F.S.; Jasprica, N. Rare plant communities of the Vis Archipelago (Croatia). Bot. Lett. 2019, 167, 1-14. [CrossRef]

90. Jackson, D.A.; Somers, K.M. Putting things in order: The ups and downs of detrended correspondence analysis. Am. Nat. 1991, 137, 704-712. [CrossRef]

91. Hill, M.O.; Gauch, H.G. Detrended Correspondence Analysis: An Improved Ordination Technique. Vegetatio 1980, 42, 47-58. [CrossRef]

92. ter Braak, C.J.F.; Smilauer, P. CANOCO Reference Manual and CanoDraw for Windows User's Guide: Software for Canonical Community Ordination (Version 4.5); Canoco: Ithaca NY, USA, 2002.

93. Šmilauer, P.; Lepš, J. Multivariate Analysis of Ecological Data Using CANOCO 5; Cambridge University Press: Cambridge, UK, 2014; ISBN 110769440X.

94. Oksanen, J.; Kindt, R.; Legendre, P.; O’Hara, B.; Stevens, M.H.H.; Oksanen, M.J.; Suggests, M. The vegan package. Community Ecol. Packag. 2007, 10, 719.

95. Ricklefs, R.E. Evolutionary diversification and the origin of the diversity-environment relationship. Ecology 2006, 87, S3-S13. [CrossRef]

96. Becker, A.; Körner, C.; Brun, J.-J.; Guisan, A.; Tappeiner, U. Ecological and Land Use Studies Along Elevational Gradients. Mt. Res. Dev. 2007, 27, 58-65. [CrossRef]

97. R Core Team. R: A Language and Environment for Statistical Computing; R Foundation for Statistical Computing: Vienna, Austria, 2020.

98. Kent, M.; Ballard, J. Trends and problems in the application of classification and ordination methods in plant ecology. Vegetatio 1988, 78, 109-124. [CrossRef]

99. Digby, P.G.N.; Kempton, R.A. Multivariate Analysis of Ecological Communities; Springer Science \& Business Media: Berlin/Heidelberg, Germany, 2012; Volume 5, ISBN 9400931352.

100. Cleaver, G.; Brown, L.R.; Bredenkamp, G.J. The phytosociology of the vermaaks, marnewicks and buffelsklip valleys of the kammanassie nature reserve, western cape. Koedoe 2005, 48, 1-16. [CrossRef]

101. Cáceres, M.; Legendre, P. Associations between species and groups of sites: Indices and statistical inference. Ecology 2009, 90, 3566-3574. [CrossRef]

102. Reed, M.; Dougill, A.; Baker, T. Participatory indicator development: What can ecologists and local communities learn from each other. Ecol. Appl. 2008, 18, 1253-1269. [CrossRef]

103. Magiera, A.; Feilhauer, H.; Waldhardt, R.; Wiesmair, M.; Otte, A. Mapping Plant Functional Groups in Subalpine Grassland of the Greater Caucasus. Mt. Res. Dev. 2018, 38, 63-72. [CrossRef]

104. Haq, F.; Ahmad, H.; Iqbal, Z. Vegetation composition and ecological gradients of subtropical-moist temperate ecotonal forests of Nandiar Khuwar catchment, Pakistan. Bangladesh J. Bot. 2015, 44, 267-276. [CrossRef]

105. Sher, H.; Al_yemeni, M. Economically and ecologically important plant communities in high altitude coniferous forest of Malam Jabba, Swat, Pakistan. Saudi J. Biol. Sci. 2011, 18, 53-61. [CrossRef]

106. Rahman, I.U.; Khan, N.; Ali, K. Classification and ordination of understory vegetation using multivariate techniques in the Pinus wallichiana forests of Swat Valley, northern Pakistan. Sci. Nat. 2017, 104, 24. [CrossRef] [PubMed]

107. Dukes, J.; Mooney, H. Does global change increase the success of biological invaders? Trends Ecol. Evol. 1999, 1, 135-139. [CrossRef]

108. Reich, P.B. Elevated $\mathrm{CO}_{2}$ reduces losses of plant diversity caused by nitrogen deposition. Science 2009, 326, 1399-1402. [CrossRef]

109. Jafari, M.; Jafarian Jeloudar, Z. Vegetation community in relation to the soil characteristics of Rineh rangeland, Iran. Casp. J. Environ. Sci. 2010, 8, 141-150.

110. Kabir, M.; Iqbal, M.Z.; Farooqi, Z.R.; Shafiq, M. Vegetation pattern and soil characteristics of the polluted industrial area of Karachi. Pak. J. Bot 2010, 42, 661-678.

111. Shaheen, H.; Riffat, A.; Salika, M.; Firdous, S.S. Impacts of roads and trails on floral diversity and structure of Ganga-Choti forest in Kashmir Himalayas. Bosque 2018, 39, 71-79. [CrossRef]

112. Khan, S.M.; Harper, D.M.; Page, S.; Ahmad, H. Species and community diversity of vascular flora along environmental gradient in Naran Valley: A multivariate approach through indicator species analysis. Pak. J. Bot 2011, 43, 2337-2346.

113. Ellenberg, D.; Mueller-Dombois, D. Aims and Methods of Vegetation Ecology; Wiley: New York, NY, USA, 1974.

114. Srivastava, S.; Shukla, R.P. Similarity and difference of species among various plant communities across grassland vegetation of north-eastern Uttar Pradesh. Trop. Plants Res. 2016, 3, 364-369.

115. Shaheen, H.; Ullah, Z.; Khan, S.M.; Harper, D.M. Species composition and community structure of western Himalayan moist temperate forests in Kashmir. For. Ecol. Manage. 2012, 278, 138-145. [CrossRef]

116. Bano, S.; Khan, S.M.; Alam, J.; Alqarawi, A.A.; Abd_Allah, E.F.; Ahmad, Z.; Rahman, I.U.; Ahmad, H.; Aldubise, A.; Hashem, A. Eco-Floristic studies of native plants of the Beer Hills along the Indus River in the districts Haripur and Abbottabad, Pakistan. Saudi J. Biol. Sci. 2018, 25, 801-810. [CrossRef]

117. Amagai, Y.; Kudo, G.; Sato, K. Changes in alpine plant communities under climate change: Dynamics of snow-meadow vegetation in northern Japan over the last 40 years. Appl. Veg. Sci. 2018, 21, 561-571. [CrossRef]

118. Jiménez-Alfaro, B.; Girardello, M.; Chytrý, M.; Svenning, J.-C.; Willner, W.; Gégout, J.-C.; Agrillo, E.; Campos, J.A.; Jandt, U.; Kącki, Z.; et al. History and environment shape species pools and community diversity in European beech forests. Nat. Ecol. Evol. 2018, 2, 483-490. [CrossRef] 